\title{
The Perplexities of Patent Prosecution History: Procedure over Principle?
}

David Vaver

Osgoode Hall Law School of York University, dvaver@osgoode.yorku.ca

Follow this and additional works at: https://digitalcommons.osgoode.yorku.ca/scholarly_works

Part of the Intellectual Property Law Commons

\section{Repository Citation}

Vaver, David, "The Perplexities of Patent Prosecution History: Procedure over Principle?" (2021). Articles \& Book Chapters. 2839.

https://digitalcommons.osgoode.yorku.ca/scholarly_works/2839

This Article is brought to you for free and open access by the Faculty Scholarship at Osgoode Digital Commons. It has been accepted for inclusion in Articles \& Book Chapters by an authorized administrator of Osgoode Digital Commons. 
For submission to (2021) Intellectual Property Journal

\title{
Comment
}

\section{The Perplexities of Patent Prosecution History: Procedure over Principle?}

\author{
- David Vaver ${ }^{*}$
}

[I]n the infancy of Courts of Justice ... substantive law has at first the look of being gradually secreted in the interstices of procedure... It would even seem that civilised societies experience reversions towards this condition of thought... (Sir Henry Maine, Dissertations on Early Law and Custom (1883), 389)

What is it about patent legislation? Speaking for the Supreme Court in 1981, Justice Dickson, later Chief Justice, said of the disclosure provision in the Patent Act (now subsection 27(3)) that:

[i]t gives the impression of a mélange of ideas gathered at random rather than an attempt to enunciate, clearly and concisely, a governing principle or principles. This is perhaps understandable in that the section is the product of amendment over a period of many years. The language simply does not lend itself to a tight, literal interpretation. It is, and should be treated as, a parliamentary pronouncement, in general terms. ${ }^{1}$

Nearly 40 years later nothing much seems to have changed. Take the new section 53.1 of the Patent Act that took effect in 2019. It was not the product of amendment over many years, nor did it present a random mélange of ideas. It had only one idea. That was to reverse a 2000 decision of the Supreme Court in Free World Trust v Electro Santé Inc ${ }^{2}$ and allow what transpires in the Patent Office ("PO") during the processing of a patent application - its "prosecution history" - potentially to affect the scope of the patent eventually granted. Subsection 53.1(1) could have simply said that: i.e., a patent's prosecution history is relevant

\footnotetext{
* Professor of Intellectual Property Law, Osgoode Hall Law School, York University; Emeritus Professor of Intellectual Property \& Information Technology Law, University of Oxford. This Comment elaborates some points raised in D Vaver, "The Wonderful World of Patents: 'They Do Things Differently There"” (Feb 5 2021), https://www.iposgoode.ca/2021/02/the-wonderful-world-of-patents-they-do-things-differently-there/.

${ }^{1}$ Consolboard Inc v MacMillan Bloedel (Sask) Ltd [1981] 1 SCR 504, 518. Subsection 27(3)'s development is in fact more convoluted that Dickson J thought: see D Vaver, "Best Mode Disclosure in Canadian Patents" (2013) 25 IPJ 303, 316 \& 320ff.

${ }^{2}[2000] 2$ SCR 1024.
} 
and admissible to aid in the construction of a patent claim or specification. ${ }^{3}$ Instead its drafting suffers from the malady highlighted by Justice Dickson. Its governing principles are not clearly and concisely stated. They seem rather to be "secreted in the interstices of procedure." ${ }^{4}$ To give the section "a tight, literal interpretation," as some courts have already done ${ }^{5}$ therefore seems inappropriate. That approach runs counter to the Interpretation Act's direction that all statutory provisions are "deemed remedial" and so require "such fair, large and liberal construction and interpretation as best ensures the attainment of [their] objects." 6 Patent legislation is not immune from these strictures. ${ }^{7}$ An ineptly drafted provision may indeed sometimes need to be treated the way Justice Dickson treated subsection 27(3), as "a parliamentary pronouncement, in general terms."

\section{Perplexities Posed}

An example may help to highlight subsection 53.1's perplexities. ${ }^{8}$ Suppose Bert applies for a patent claiming an adhesive that combines chalk and cheese. The PO examiner asks what Bert means by "chalk" and gets the reply "white chalk." The claim could have been amended to "white chalk" but was not. The parties' exchange appears on the public file. After the patent is granted Bert tells Ruby, an adhesive maker, that she infringes by combining red chalk with cheese. Bert's distributor Ali also tells Fatima, Ruby's distributor, that she infringes by selling Ruby's product. The average skilled adhesive maker reading the patent would understand chalk to mean chalk of any hue. May the exchange of letters on the PO file be used to limit the patent to white chalk?

\footnotetext{
${ }^{3}$ The other subsections of s 53.1 applying to disclaimers, re-examination, reissue, divisional applications, and supplementary protection certificates are not specifically considered here: see Patent Act, RSC 1985 c P-4, subss $53.1(2) \& 53.1(3) \& \mathrm{~s} 123.1$.

${ }^{4}$ H. Maine, Dissertations on Early Law and Custom (1883), 389.

${ }^{5}$ Eg Gemak Trust v Jempak Corp 2020 FC 644 at [86] applying the "presumption against the legislature impliedly changing established law, particularly the common law."

${ }^{6}$ Interpretation Act, RSC 1985, c I-21, s 12.

${ }^{7}$ Karolinska Institutet Innovations AB v Canada (A-G), 2013 FC 715 at [33]-[8] [Karolinska].

${ }^{8}$ Based on the example in D Vaver, Intellectual Property Law: Copyright, Patents, Trade-marks, 2nd ed (Toronto: Irwin Law 2011), 348-9.
} 
Here is what subsection 53.1(1) says:

In any action or proceeding respecting a patent, a written communication, or any part of such a communication, may be admitted into evidence to rebut any representation made by the patentee in the action or proceeding as to the construction of a claim in the patent if

(a) it is prepared in respect of

(i) the prosecution of the application for the patent...

(b) it is between

(i) the applicant for the patent or the patentee; and

(ii) the Commissioner [or] an officer or employee of the Patent Office... (emphasis added)

Two perplexities are immediately apparent. The emphasised words focus only on (i) court proceedings and (ii) a patentee's representation. If the subsection is interpreted literally, it would mean that both Bert's and Ali's representations, being made outside of court, are inadmissible; ${ }^{9}$ and Ali's is barred for the further reason that he is not the patentee. The Supreme Court in Free World said that to admit prosecution history would be to create uncertainty and litigiousness. ${ }^{10}$ If subsection 53.1(1) merely changes full inadmissibility to only partial inadmissibility, it adds to the vices alleged by Free World a new one: arbitrariness leading to potential injustice. The reform of substantive law would be partly thwarted by its being secreted in the interstices of procedure.

Consider two examples:

(1) Ruby sues Ali for injurious falsehood for maligning her adhesive to her distributor Fatima. ${ }^{11}$ On a literal interpretation of subsection 53.1(1), Ruby will fail, for Ali can avoid judgment simply by filing no defence. Even if Ruby's lawsuit is one "respecting a patent" (as it probably is), Ali's representation is not made "in any action or proceeding" and so Ruby has nothing to rebut. She cannot get judgment by default against Ali if the only evidence she has of a false allegation of infringement is inadmissible prosecution history.

\footnotetext{
${ }^{9}$ Claim construction in the PO during prosecution is however unaffected by the applicant's representations: $R e$ Intercontinental Exchange Holdings Inc 2020 CACP 27 (Comm'r Patents).

${ }^{10}$ Free World, n 2 at 1061.

${ }^{11}$ A false allegation of infringement is actionable at common law or under subs 7(a) of the Trademarks Act, RSC 1985, c T-13: S \& S Industries Inc v Rowell [1966] SCR 419.
} 
(2) Ali sues Ruby and Fatima for patent infringement, as any of Bert's distributors may if Bert is joined as co-defendant. ${ }^{12}$ Neither Ruby nor Fatima can raise any prosecution history because Ali, who makes the representation, is not the patentee - as one court has already held in the stronger case where the representor was an exclusive licensee. ${ }^{13}$ So patentees can hide their dodgy prosecution history simply by having any distributor, affiliate, or indeed downstream buyer sue competitors for infringement. ${ }^{14}$

\section{Perplexities Pre-empted}

Such absurd results are avoidable if one looks at what exactly the Supreme Court in Free World decided and therefore what section 53.1 is targeting. Free World held that prosecution history was (a) irrelevant and therefore (b) inadmissible to help interpret a patent claim. ${ }^{15}$ The drafting of subsection 53.1(1) however says nothing about relevancy and speaks only of admissibility. In stating that prosecution history is admissible, the subsection nevertheless necessarily implies it is relevant; for irrelevant evidence is never admissible in legal proceedings. But if prosecution history is relevant to construction, it must be relevant to construction everywhere, in or out of court, including where potential parties are getting legal advice or sending letters before action.

Such a view allows Bert's claim covering "chalk" to be read to cover only "white chalk," and Ruby can use Ali's representation in her injurious falsehood suit. She can rightly say that Bert's patent - a document issued by the government - cannot mean one thing before it is litigated and another later. That is true of statutes, wills, contracts, deeds, legal notices - and patents. ${ }^{16}$

\footnotetext{
${ }^{12}$ Signalisation de Montréal Inc v Services de Béton Universels Ltée [1993] 1 FC 341 (CA).

${ }^{13}$ Allergan Inc v Sandoz Canada Inc 2020 FC 1189 at [133] [Allergan]. It is odd that the licensee's representations were not read as made on behalf of both itself and the co-defendant patentee. The licensee and the patentee clearly both made common cause even if the patentee chose to lie silent in the weeds.

${ }^{14}$ Patent Act, n 3, s 55(1), giving "all persons claiming under the patentee" the right to sue for infringement has progressively been held to include anyone "who derives his rights to use the patented invention, at whatever degree, from the patentee:" McCain Foods Ltd v J.R. Simplot Co 2021 FCA 4 at [78].

${ }^{15} \mathrm{~N} 2$ at 1061.

16 "[T]here has been a harmonisation of the interpretation of contracts, unilateral notices, patents and also testamentary documents" although "[d]ifferences in the nature of documents will influence the extent to which
} 
Subsection 53.1(1) deals with the most common application of the principle admitting prosecution history: that of the patentee who argues in court for a construction that is inconsistent with what was represented to the PO. But a patent's construction is a question of law and that remains constant, whoever argues for or against it. Indeed a court can hold a patent to mean something different from what either party says it means: even an agreement by both parties does not bind the court. So just because subsection 53.1(1) refers to the most common application of the principle of admissibility - a defendant's rebuttal of a patentee's representation in court - nothing suggests that others in less common situations should be gagged. True, as has been pointed out, the Act's definition of "patentee" does not include licensees or distributors, ${ }^{17}$ but a definition section applies "only if a contrary intention does not appear," and a literal application here would undercut the provision's remedial purpose. ${ }^{18}$ Justice is not served if a court has to conclude that a patent means $\mathrm{X}$ in Case $\mathrm{X}$ and $\mathrm{Y}$ in Case $\mathrm{Y}$ simply because prosecution history is excluded in Case $\mathrm{X}$ when a licensee, intervener, or amicus is making the argument, ${ }^{19}$ but is included in Case $\mathrm{Y}$ when the patentee makes it. Things get worse if the plaintiff wins in Case $\mathrm{X}$ but loses in Case $\mathrm{Y}$ simply because of the exclusion of the evidence in $\mathrm{X}$ and its admission in $\mathrm{Y}$.

Those unwilling to go as far as treating subsection 53.1(1) "as a parliamentary pronouncement, in general terms" should at least accept that legislation these days that modifies the common law is not usually interpreted strictly, in light of the contrary direction

the court may look at the factual background to assist interpretation:" Trump Int'l Golf Club Scotland Ltd v Scottish Ministers [2015] UKSC 74 at [33] (emphasis added). We need not here enter the thorny question of whether a patent is also an "enactment" (Interpretation Act, n 6, s 2) and so equally caught by the "fair, large, and liberal" language of $\mathrm{s} 12$ of the latter Act: on which see Vaver, n 8 at 348 (n 406) contra.

${ }^{17}$ Patent Act, n 3, s 2 def "patentee", contrasting with subs 55(1) which goes further to allow infringement actions to be brought not merely by the "patentee" but by "all persons claiming under the patentee:" see further $\mathrm{n} 14$.

${ }^{18}$ Interpretation Act, n 6, para 15(2)(a); see Veuve Clicquot Ponsardin v Boutiques Cliquot Ltée 2006 SCC 23 at [48] where a provision in the Trademarks Act was interpreted non-literally.

19 As in Free World itself, $\mathrm{n} 2$, where an intervener was making the argument on construction, except it was arguing for admission of the prosecution history: the defendant by then had gone bankrupt and did not appear in the SCC to uphold the judgment in its favour (ibid at 1032 \& 1059). It is possible for the boot to be on the other foot and for an intervener or amicus to argue against admission where a patentee plaintiff does not appear. 
in the Interpretation Act noted above. ${ }^{20}$ More than a century ago, Justice Holmes noted that, while courts often refused to extend such statutes "beyond the direct operation of the words used," not all legislation should be treated that way:

A statute may indicate or require as its justification a change in the policy of the law, although it expresses that change only in the specific cases most likely to occur to the mind. The legislature has the power to decide what the policy of the law shall be, and if it has intimated its will, however indirectly, that will should be recognized and obeyed. The major premise of the conclusion expressed in a statute, the change of policy that induces the enactment, may not be set out in terms, but it is not an adequate discharge of duty for courts to say: We see what you are driving at, but you have not said it, and therefore we shall go on as before. ${ }^{21}$ (emphasis added)

It is not difficult to discern what subsection 53.1(1) is driving at. Its major premise that prosecution history is henceforth relevant to claim construction - is "not set out in terms," but it is necessarily implied in the admissibility, and thus relevance, of that history for that purpose. The subsection has also expressed the change of policy from Free World "only in the specific cases most likely to occur to the mind" - the patentee who in court proffers a construction different from the history. The provision however does not imply that less common cases are subject to a different policy, and no rational explanation can be presented why they should be.

It follows that Justice Grammond was right in Bauer Hockey Ltd v Sport Maska Inc ${ }^{22}$ in saying there was "no need to identify a particular representation and rebuttal every time a reference is made to the prosecution history" and that the history was "simply integrated in the interpretive process." For him, claim construction always involves the patentee "making representations to the Court as to the proper construction of the claims and the defendant ... always attempting to rebut those representations." That justification could, with minor modification, cover cases where construction is being argued outside a patent proceeding or by a non-patentee. One may need to add the rider that subsection 53.1(1) is not intended to

\footnotetext{
${ }^{20} \mathrm{~N}$ 6, s 12; see also Karolinska, n 7 at [33]-[8].

${ }^{21}$ Johnson v US 163 F 30, 32 (1st Cir 1908), sitting by designation.

222020 FC 624 at [65]; see also Janssen Inc v Teva Canada Ltd 2020 FC 593 at [140]-[4].
} 
be exhaustive and its remedial intention also covers the latter cases to promote consistency of construction and the avoidance of unequal treatment and thus injustice.

These are not the only perplexities presented by subsection 53.1(1). Its raison d'être is worth probing further before the issue of using foreign prosecution history is considered.

\section{Principle Posited}

Section 53.1's enactment in 2018 seems designed to bring patent law up with trends that have been developing for some time in the general law. These developments (i) let the surrounding circumstances in which a document is set assist its interpretation, ${ }^{23}$ (ii) discard or minimize technical rules that hinder that process, ${ }^{24}$ and (iii) allow the once impregnable fortress of formal writings to be breached by representations that induced them. ${ }^{25}$ A patent applicant's representation may thus help delineate the scope of the claims and what infringes it. ${ }^{26}$ Outside the world of patents, had Bert promised in writing to sell "chalk" to Ruby after earlier promising her "white chalk," Ruby could not be stuck with a truckload of red chalk. While the writing may at first sight seem the final conclusive record of Bert and Ruby's bargain, second sight dispels this myopia. To ignore evidence of the whole transaction would defraud Ruby and give Bert a windfall, enabling him to foist any colour chalk on her.

Section 53.1 largely dispatches the curate's egg the Supreme Court delivered in Free World when it confirmed that "the patentee and potential infringers are both bound by the terms of the patent as issued," whatever previously transpired in the PO ${ }^{27}$ In doing so the Court chose to ignore earlier decisions of its own that had used both foreign and domestic

${ }^{23}$ Sattva Capital Corp v Creston Moly Corp 2014 SCC 53 at [46].

${ }^{24}$ Ibid at [47].

25 Eg Zippy Print Enterprises Ltd v Pawliuk (1994) 100 BCLR (2d) 55, 1994 CanLII 1756 at [32]-[41] (CA); Bolkiah $v$ State of Brunei Darussalam [2007] UKPC 63 at [47]; Thinc Group Ltd v Armstrong [2012] EWCA Civ 1227 at [83]ff, D Nicholls, "My Kingdom for a Horse: The Meaning of Words" (2005) 121 LQR 577, 587-8 [Nicholls]. Compare the more conservative view in Lumber Underwriters of NYv Rife 237 US 605, 609 (1915) (insurance policy); Chartbrook Ltd v Persimmon Homes Ltd, [2009] UKHL 38 at [32] \& [41] (building development), rejecting Nicholls, ibid.

${ }^{26}$ CanMar Foods Ltd v TA Foods Ltd 2019 FC 1233 at [68], aff'd 2021 FCA 7 [CanMar].

${ }^{27}$ PLG Research Ltd v Jannock Steel Fabricating Co (1991) 35 CPR (3d) 344, 349 (Fed TD), aff'd (1992) 41 CPR (3d) 492 (Fed CA); approved in Free World, n 2 at 1061. 
prosecution history to affect the scope of domestic patent and trademark rights. ${ }^{28}$ The Court instead chose to treat the culprit as being the US's doctrine of prosecution history or "file wrapper" estoppel - jargon for the simple idea that a patent's scope should square with what the applicant told the PO about it before grant. ${ }^{29}$ The Court went on to disapprove of the US rule: adopting it in Canada would "undermine the public notice function of the claims, and increase uncertainty as well as fuelling the already overheated engines of patent litigation." 30 Common law elsewhere on patents reached similar results. ${ }^{31}$ The Supreme Court however let sit a Federal Court decision it cited which had held that "information contained in file wrappers, either domestic or foreign, may be relevant for some purposes on some occasions." ${ }^{32}$ Courts then and since did use such information for other purposes: e.g., to draw inferences about a claim's features and the prior art, or to help decide whether a specification was wilfully misleading or particular remedies for infringement should be withheld. ${ }^{33}$ Such

\footnotetext{
${ }^{28}$ Eg Minerals Separation North America Corp v Noranda Mines Ltd [1950] SCR 36, 52, 58 \& 68, aff'd (1952) 69 RPC 81 (PC) (US prosecution history confirms Canadian claim interpretation); Laboratoire Pentagone Ltée c Parke Davis \& Co [1968] RCS 307, 312-3 (assertions in Swiss patent application undermine Canadian assertions) [Pentagone]; SC Johnson \& Son Ltd v Marketing Int'l Ltd [1980] 1 SCR 99, 113-4 (trademark's scope aligned with representations to Canadian Trademarks Office) [Johnson]; Parke Davis \& Co v Empire Laboratories Ltd [1964] SCR 351, 357 (US patent file shows functionality and thus unregistrability of Canadian trademark) [Parke Davis]; similarly Hatmaker $v$ Joseph Nathan \& Co Ltd (1919) 36 RPC 231, 237-8 (HL) (admissions on US patent file evidence of inutility in UK); compare W Hayhurst, "Recent Developments in Canada Law: Intellectual Property" (1987) 19 Ottawa L Rev 137, 146-8.

${ }^{29}$ The bundle of documents that includes the patent application and the history of external and internal communications on it are wrapped up into a file in the US - hence "file wrapper."

$30 \quad$ Free World, n 2 at 1061, criticized in Vaver, n 7 at 348-50.

${ }^{31}$ Kirin-Amgen Inc v Hoechst Marion Roussel Ltd [2004] UKHL 46 at [35], [39]-[40] \& [44]; Russell Finex Ltd v Telsonic AG [2004] EWHC 474 at [27]-[30] (Ch); Lynx Engineering Consultants Pty Ltd v Pilbara Infrastructure Pty Ltd [2016] FCAFC 19 at [77]ff (Aust Full Fed Ct); Ranbaxy Laboratories Ltd v Warner Lambert Co [2006] 1 IR 193 (Ire SC). Compare on the US rule, R Schechter \& J Thomas, Intellectual Property: The Law of Copyrights, Patents \& Trademarks (St Paul, Minn: Thomson/West 2003), 491ff.

${ }^{32}$ Foseco Trading AGv Canadian Ferro Hot Metal Specialties Ltd (1991) 36 CPR (3d) 35, 47 (Fed TD) [Foseco], cited in Free World, n 2 at 1062.

${ }^{33}$ Hatton v Copeland Chatterson Co 1906 CarswellNat 10 at [8] (Ex), aff'd (1906) 37 SCR 651 [Hatton] (comparing US patent); Distrimedic Inc v Dispill Inc 2013 FC 1043 at [210]; NOV Downhole Eurasia Ltd v TLL Oil Field Consulting Ltd 2014 FC 889 at [31]-[2]; Eli Lilly Can. Inc v Mylan Pharmaceuticals ULC 2015 FC 125 at [154]; Safe Gaming System v Atlantic Lottery Corp 2018 FC 542 at [176]; but see Valeant Can. LP/Valeant Can. SEC v Ranbaxy Pharmaceuticals Can. Inc 2018 FC 847 at [38]-[40] (foll'ing Free World).
} 
cases seem unaffected by section 53.1, which does not try to regulate the effect of every statement made to the PO. ${ }^{34}$

The Supreme Court's decision to encourage applicants to be economical with the truth in their dealings with the PO did not attract universal acclaim. In 2016 a judge described the gap between what a patent holder was telling him about validity and infringement and what it had told the PO to get its patent as "breathtaking:" it would never have worked in the US, he added. ${ }^{35}$ Then in 2017 the almost unthinkable happened in the UK: its highest court unanimously reversed an equally unanimous decision of its own from just 13 years earlier and now accepted, albeit grudgingly, that the PO file contents may - exceptionally — aid claim construction. This could occur where (i) the specification and claims are ambiguous "and the contents of the file unambiguously resolve the point" or, more broadly, (ii) "it would be contrary to the public interest for the contents of the file to be ignored." 36 That view, if applied to the chalk hypothetical above, would justify limiting that claim to white chalk. And so it should, because:

- the general law of evidence usually allows anything a party does or says to be held against them; $; 7$

- admission stops people blowing hot and cold: ${ }^{38}$ e.g., a trademark registrant cannot assert rights inconsistently with representations it made to CIPO to obtain registration; ${ }^{39}$

- admission promotes consistency among Canadian and corresponding foreign patents: evidence that causes a US patent to be found invalid or not infringed should not be gagged when its Canadian counterpart is litigated; 40

\footnotetext{
${ }^{34}$ Notwithstanding Allergan, n 13 at [118], obiter.

${ }^{35}$ Pollard Banknote Ltd v Scientific Games Product (Can.) ULC 2016 FC 883 at [237] [Pollard], loyally following Free World, $\mathrm{n} 2$, but still finding invalidity and non-infringement.

${ }^{36}$ Eli Lilly \& Co v Actavis UK Ltd [2017] UKSC 48 at [88].

${ }^{37}$ D Paciocco \& L Stuesser, The Law of Evidence, $7^{\text {th }}$ ed (Toronto: Irwin Law 2015), 158ff.

${ }^{38}$ Brunette v Legault Joly Thiffault SENCRL 2018 SCC 55 at [39].

39 Johnson, n 26 at 113-4; Venngo Inc v Concierge Connection Inc 2017 FCA 96 at [64].

${ }^{40}$ The anomaly, tolerated by Free World, n 2 at 1061, against which the judge chafed in Pollard, n 35 at [236]-[9].
} 
- much of the patent file is publicly available online and is often gleaned for use at trial or when legal advice is sought - a point the Supreme Court seemingly accepted, while coyly not saying when or how the admitted relevance of the file "for some [unspecified] purposes on some [unspecified] occasions" promoted the certainty or simplicity in litigation it was advocating; ${ }^{41}$

- certainty and simplicity are anyway not absolute values, and both Canadian and American law routinely let prior representations prevail over formal written documents in other contexts where justice demands. ${ }^{42}$

\section{Foreign Perplexities}

Section 53.1 could also have said something specific about the permissible use of the prosecution history of any related or foreign patent, but did not and instead simply left it for courts to work out. They are having trouble doing so. In CanMar Foods Ltd v TA Foods Ltd ${ }^{43}$ the Federal Court found that certain features of a method claim were essential and that the defendant's method, lacking those features, therefore did not infringe. Justice Manson said he could decide these questions summarily without expert evidence or reference to the application's prosecution history. He nevertheless said his conclusion was supported by that history. The applicant had introduced amendments in Canada that limited the claim. Although the reason for the amendments did not appear in the Canadian file, Justice Manson said that section 53.1(1) allowed him to look at what the applicant had told the PO was "a related" US file. The same amendments were proffered specifically in the US to avoid the application's rejection there over the very prior art the defendant was using.

On appeal, the Federal Court of Appeal, while upholding Justice Manson's conclusion of non-infringement, disapproved of his use of prosecution history to support it. The Court of Appeal said it was "wary" about using foreign history even where it was "useful." It apparently would have overcome its wariness had the Canadian application claimed priority

\footnotetext{
${ }^{41}$ Free World, ibid at 1062, citing Foseco, n 32 at 47 to this effect.

${ }^{42} \mathrm{~N} 25$.

${ }^{43} \mathrm{~N} 26$ at [77]-[8], [86]-[94], \& [99]ff(FC).
} 
from the US one and expressly referred to it. ${ }^{44}$ Subsection 53.1(1) however made only Canadian prosecution history admissible and the Canadian reference to an unspecified "related" US application that was later abandoned was not specific and clear enough to "incorporate" its contents into the Canadian file. ${ }^{45}$

If the Court of Appeal is correct, its requirement of specificity and clarity would equally exclude admission of "a related" Canadian application. It would also make taciturn applicants generally better off than those who come clean with the PO. ${ }^{46}$ But why must there be any reference at all to the second file for it to be looked at, whether it be domestic or foreign? No such reference was required in a Supreme Court case in 1968 where an applicant's assertion that its invention involved a chemical process was allowed to be disproved by the applicant's contrary assertion in a parallel application in Switzerland. ${ }^{47}$ Similarly, the question in CanMar - "how does the Canadian amendment rebut the patentee's contrary representation?" - can be answered: "Because the reasons for the amendment appear in a parallel US prosecution; and so the Canadian amendment, with those reasons, may be used to rebut the representation." Even if some sort of cross-reference were required, there seems no reason why the rule in patent law should be stricter than in the general law: there two documents that "do not expressly refer to each other" can be interlinked by a "connection and reference [that is] a matter of fair and reasonable inference." 48 Where either document is located seems irrelevant.

\section{Freeing the World from Free World}

\footnotetext{
${ }^{44}$ CanMar, ibid at [73] \& [76] (FCA).

${ }^{45}$ Ibid at [76].

${ }^{46}$ Compare BVD Co Ltd v Canadian Celanese Ltd [1937] SCR 221, 230, further proceedings [1937] SCR 441, 4489, aff'd 1939] 2 DLR 289 (PC); Hatton, n 33 at [8].

${ }^{47}$ Pentagone, n 28 at 312-3 (such an invention, though patentable in Switzerland, was then not so in Canada); also Parke Davis, n 28 at 357, holding US patent file renders Canadian trademark unregistrable for functionality despite no reference in the Canadian application to the US file.
}

${ }^{48}$ Doran v McKinnon (1916) 53 SCR 609, 611, applied in Druet v Girouard 2012 NBCA 40 at [34]. Similarly elsewhere: see eg Crabtree v Elizabeth Arden Sales Corp 305 NY 110 (CA 1953) (representing the prevailing US view, contrary to Paice LLC v Ford Motor Co 881 F 3d 894, 906-7 (Fed Cir 2018) relied on by the FCA in CanMar, n 25 at [76]); Elias v George Sahely \& Co (Barbados) Ltd [1983] 1 AC 646 (PC); Mackay Sugar Ltd v Quadrio [2015] QCA 41 at [29] (Qd CA). 
The Court of Appeal's ambivalence in CanMar about foreign history may be understandable given that its views were obiter: the trial judge said he would have reached the same conclusion with or without the history. One however wonders whether the Court would have been as ambivalent had the trial judge reached a conclusion at odds with the excluded history something difficult to ascertain unless the history had been admitted provisionally (de bene esse). Would it have been equally "wary" had CanMar's representations appeared in a "related" unspecified but identifiable Canadian file? The Supreme Court in Free World set itself equally against both domestic and foreign prosecution history to help construe claims. But once subsection 53.1(1) is understood as directing that Canadian history is relevant, foreign history is no less so today than it was in the Supreme Court in 1968. As earlier argued, subsection 53.1(1) does deal with the typical case of domestic history, but it does not positively exclude less typical cases such as those seeking to use relevant foreign history. May one not recognize section 53.1 as a provision that intends to change previous policy and re-establish prosecution history as a relevant factor in claim construction generally - so that the world may be freed from Free World, root and branch? 